\title{
Comparison of the Postharvest Characteristics of Mango Fruits Produced under Contrasting Agro-Ecological Conditions and Harvested at Different Maturity Stages
}

\author{
Jane Ambuko ${ }^{1}$, Nancy Kemunto ${ }^{1}$, Margaret Hutchinson ${ }^{1} \&$ Willis Owino $^{2}$ \\ ${ }^{1}$ Department of Plant Science and Crop Protection, University of Nairobi, Kangemi, Nairobi, Kenya \\ ${ }^{2}$ Department of Food Science and Technology, Jomo Kenyatta University of Agriculture \& Technology, Nairobi, \\ Kenya \\ Correspondence: Jane Ambuko, Department of Plant Science and Crop Protection, University of Nairobi, P. O. \\ Box 29053-00625, Kangemi, Nairobi, Kenya. E-mail: ambuko@yahoo.com
}

$\begin{array}{lcc}\text { Received: June 4, } 2017 & \text { Accepted: July 3, } 2017 & \text { Online Published: July 15, } 2017 \\ \text { doi:10.5539/jas.v9n8p181 } & \text { URL: https://doi.org/10.5539/jas.v9n8p181 }\end{array}$

This research was financed by the Government of Kenya through the Kenya Agricultural Productivity and Agribusiness Project (KAPAP).

\begin{abstract}
Mango (Mangifera indica) fruit production in Kenya occurs under diverse agro-ecological zones (AEZs). The different AEZs have variations in rainfall, sunlight, temperature, soils and cultural practices all of which affect fruit physiology and quality at harvest. Maturity stage at harvest also affects mango fruit quality and storage potential. In the present study, the effect of AEZs and fruit maturity stage on the postharvest shelf-life of mango variety apple was determined. The study was conducted over two seasons in 2011 and 2013 and the fruits were harvested from two different AEZs: Embu (high potential zone) and Makueni (low potential zone). The fruits were also harvested at two maturity stages based on flesh color. The fruits were selected for uniformity and allowed to ripen at ambient room conditions (Temperature; $25 \pm 1{ }^{\circ} \mathrm{C}$ and $\mathrm{RH} 60 \pm 5 \%$ ) until a predetermined end stage. Five fruits were randomly sampled from each batch for determination of respiration, cumulative weight loss, total soluble solids, titratable acidity, ascorbic acid and mineral nutrients (potassium and magnesium). The results showed that 'apple' mango fruit quality was significantly affected by production location, maturity stage and the interaction between the two factors. Fruits harvested from Makueni and fruits harvested at early maturity stage (S1) had a longer shelf life (3 days more). Makueni fruits had significantly $(\mathrm{p}<0.05)$ lower respiration rates accompanied with minimal weight loss. In addition, total soluble solids (TSS), ascorbic acid and mineral (magnesium) were significantly $(\mathrm{p}<0.05)$ high in Makueni fruits while fruits from Embu were significantly $(\mathrm{p}<$ 0.05 ) high in total titratable acidity and potassium content. This study confirms profound variability in fruit quality as affected by the production location and harvest maturity.
\end{abstract}

Keywords: shelf-life, fruit quality, maturity, maturity index

\section{Introduction}

Mango (Mangifera indica L.) is one of the most popular fruits in Kenya which is consumed for its nutritious and medicinal value. Mango is adapted to a wide range of climatic conditions. In Kenya, mango production occurs in most of the seven AEZs ranging from sub-humid to semi-arid (Griesbach, 2003). Variation in climatic factors in these AEZs variably affect fruit growth and development and subsequently on their postharvest shelf-life and quality (Kays, 1999).

Production zone and the season in which the fruits are produced influence nutritional composition including ascorbic acid, carotenoids, thiamine and flavonoid contents (Silva et al., 2008). Temperature variation during the season of fruit production greatly impact on the growth rate and fruit development through an influence on the rate of mineral nutrients uptake from the soil (Austin et al., 1999). This can significantly affect the fruit quality and postharvest characteristics (Ambuko et al., 2006). 
Light is an important production factor that influences fruit tree photosynthetic activity, fruit pigmentation and peel structure (Hewett, 2006). The amount of light intercepted into the tree canopy affects the accumulation of coloration pigments through its influence on anthocyanin production (Simmons et al., 1998a). High light intensity during mango fruit production has been associated with lower fruit acidity and high sugar content due to increased dry matter accumulation (Hofman et al., 1995). Ascorbic acid content in mango is reported to be affected by the amount of light received during production period. The lower the light intensity the lower the ascorbic acid content of the fruit (Hollinger, 1996). Water is an important component that is necessary for all the biochemical reactions occurring in plants during growth. During fruit production, enough water should be supplied to the mango tree during critical periods especially before flowering (Simmons et al., 1995). Water availability will influence the final mango fruit quality and postharvest behavior (Behboudian \& Mills, 1997). Excess water supplied to mango trees results to excessive turgidity leading to increased susceptibility to physical damage, reduced firmness, delayed maturity and reduced soluble solids content (Simmons et al., 1995).

Fruit maturity at harvest has a significant effect on their postharvest characteristics and quality (Crisosto et al., 1995). Often fruits are harvested at different maturity stages depending on the target market. Mango fruits destined for regional and international markets are usually harvested at early maturity stage compared to fruits harvested for the local market (HCDA, 2010).

The objective of this study was to establish the effect of agro-ecological zones on the post-harvest shelf life of 'apple' mango produced from two different agro-ecological zones; a high potential agro-ecological zone, III, (Embu) and a low potential agro-ecological zone, V, (Makueni).

\section{Materials and Methods}

The fruits used in the present study were harvested from twelve mango trees of approximately the same age (6-7 years) in commercial orchards in Embu and Makueni counties. Embu County is semi-humid and lies in AEZ III of Kenya. Embu lies at $1200 \mathrm{~m}$ above sea level with mean annual temperature of $19{ }^{\circ} \mathrm{C}$ and annual rainfall between $950 \mathrm{~mm}$ to $1350 \mathrm{~mm}$. Embu soils are fertile and rich in organic content. The soils are high in potassium $(1.48 \mathrm{ppm})$ and nitrogen $(0.12 \%)$ nutrients. Makueni County is a low potential zone found in AEZ V of Kenya, lies at $450 \mathrm{~m}$ above sea level and receives an annual average rainfall of $550 \mathrm{~mm}$ or less. The mean annual temperature varies between $26{ }^{\circ} \mathrm{C}$ to $35^{\circ} \mathrm{C}$. Makueni soils are a combination of sandy-loam with relatively lower nutrient content. Soil test indicated lower $\mathrm{N}$ content $(0.07 \%)$, organic carbon $(0.52 \%)$ and potassium nutrient $(1.40 \mathrm{ppm})$ in Makueni orchard soils.

The study was conducted between 2011 and 2013. Using fruit peel/pulp color and 'shoulder' orientation as maturity indices, the fruits were harvested at stage 1 (flesh mostly white, just turning yellow near the seed) and stage 2 (flesh mostly yellow, turning orange at the seed). The harvested were immediately transported to the postharvest laboratory and washed in water containing $1 \%$ acetic acid to disinfect and then left to dry in open air. The fruits from each stage harvested from the different location were then batched and arranged in single layers on plastic trays which were then separately stored for evaluation of their shelf life under ambient room conditions (Temperature; $25 \pm 1{ }^{\circ} \mathrm{C}$ and $\mathrm{RH} 60 \pm 5 \%$ ). From each batch, five fruits were randomly selected for analysis of changes in parameters associated with mango ripening. This was done after every three or five days in (seasons 1 and 2) respectively. In both seasons, five fruits from each batch were selected at the beginning, weighed and labeled (1-5) for daily evaluation of respiration rate, ethylene evolution and fruit weight measurement.

\subsection{Determination of Respiration Rate}

Five fruits were put in plastic jars of $5775 \mathrm{ml}$ whose covers were fitted with a self-sealing rubber septum for gas sampling. The fruits were then incubated for two hours at room temperature $25{ }^{\circ} \mathrm{C}$. Gas samples from the headspace gas were taken using an airtight $1 \mathrm{ml}$ hypodermic syringe and injected into gas chromatograph (Model GC-8A, Shimadzu Corp., Kyoto, Japan). The gas chromatograph was fitted with a thermal conductivity detector (TCD) and a Poropak N column. The rate of carbon dioxide production was expressed as ml per Kg per Hour at standard atmospheric pressure.

\subsection{Weight Loss Determination}

The fruits from each treatment batch were clearly numbered (1 to 5$)$ and weighed daily using a scientific balance (Model Libror AEG-220, Shimadzu Corp. Kyoto, Japan). The initial weight $\left(\mathrm{W}_{1}\right)$ of each fruit at day 0 and the new weight of the same fruit $\left(\mathrm{W}_{2}\right)$ on each sampling day were noted. The formula below was used to calculate the cumulative weight loss (\%):

$$
\text { Cumulative weight loss }(\%)=\left(\mathrm{W}_{1}-\mathrm{W}_{2}\right) / \mathrm{W}_{1} \times 100
$$




\subsection{Determination of Total Soluble Solids}

Total soluble solids content was determined using a digital hand refractometer (Model 500, Atago, Tokyo, Japan). On each destructive sampling day, five milliliters of mango juice was extracted from three different fruits and placed on the hand refractometer to establish the total soluble solids which was expressed as ${ }^{\circ}$ Brix.

\subsection{Determination of Total Titrable Acidity}

Total titratable acidity was determined by titration. Five milliliters of the mango juice extracted was diluted with $25 \mathrm{ml}$ of distilled water. Only $10 \mathrm{ml}$ of the diluted juice was used for titration with $0.1 \mathrm{~N}$ Sodium Hydroxide using phenolphthalein as an indicator.

\subsection{Ascorbic Acid Determination}

The ascorbic acid was determined according to AOAC (1996) method number 1 of dye titration. Five milliliters of the juice was topped up with $10 \%$ trichloroacetic acid (TCA) in $100 \mathrm{ml}$ volumetric flask. The indicator used (2,6-dichlophenolindophenol) was titrated into $10 \mathrm{ml}$ of the fruit juice extracted.

\subsection{Minerals Determination}

Minerals (potassium and magnesium) were analyzed using the AOAC (1996) method. Five grams of the pulp was charred in the oven for 30 minutes then put in a muffle furnace at $550{ }^{\circ} \mathrm{C}$ for eight hours to ash. The ash was allowed to cool and diluted with $10 \mathrm{ml}$ of $1 \mathrm{~N}$ hydrochloric acid. The mixture was filtered and diluted with 100 $\mathrm{ml}$ of distilled water. Magnesium was analyzed using an atomic absorption spectrophotometer (Model AA-6200, Shimadzu Corp., Kyoto, Japan) while potassium was analyzed using flame emission photometer (Model FA-410, Shimadzu Corp., Kyoto, Japan).

\subsection{Statistical Analysis}

Data was analyzed using Genstat statistical package $14^{\text {th }}$ edition. Comparison of means was done by Analysis of Variance (ANOVA) and Least Significance Difference (LSD) at $\mathrm{p} \leq 0.05$. The data is presented as graphs and tables showing the changing trends for various parameters based on the main treatment effects.

\section{Results}

\subsection{Respiration Rate and Fruit Shelf-Life}

Respiration rate followed a typical climacteric pattern with a gradual rise to peak levels followed by a decrease until the end of storage (Figures 1A and 1B). Higher respiration rates were observed in stage 2 (S2) fruits compared to those harvested at stage 1 (S1) irrespective of the production location and season. In season 1, fruits from Makueni had generally lower respiration rates and ultimately smaller respiration peaks 53.5 and 56.1 $\mathrm{ml} / \mathrm{kg} /$ hour (S1 and S2 respectively) compared to 57.6 and $59.8 \mathrm{ml} / \mathrm{kg} /$ hour for fruits from Embu. Significantly higher respiration rates were reported in season 2 compared to season 1. Fruits from Makueni had significantly $(\mathrm{p}<0.05)$ lower respiration rate and lower peak levels, 54.0 and $55.3 \mathrm{ml} / \mathrm{kg} /$ hour compared to 75.4 and 78.2 $\mathrm{ml} / \mathrm{kg}$ /hour (S1 and S2 respectively) for fruits from Embu. In season 2, respiration rate was significantly ( $<<$ 0.001 ) affected by the interaction between location and stage of maturity.

Overall based on respiratory activity, fruits harvested at early maturity (S1) had a relatively longer shelf life of 10 and 13 days (Embu and Makueni respectively) compared to 8 and 9 days for those harvested at (S2) (Figure $1 \mathrm{~A})$. 

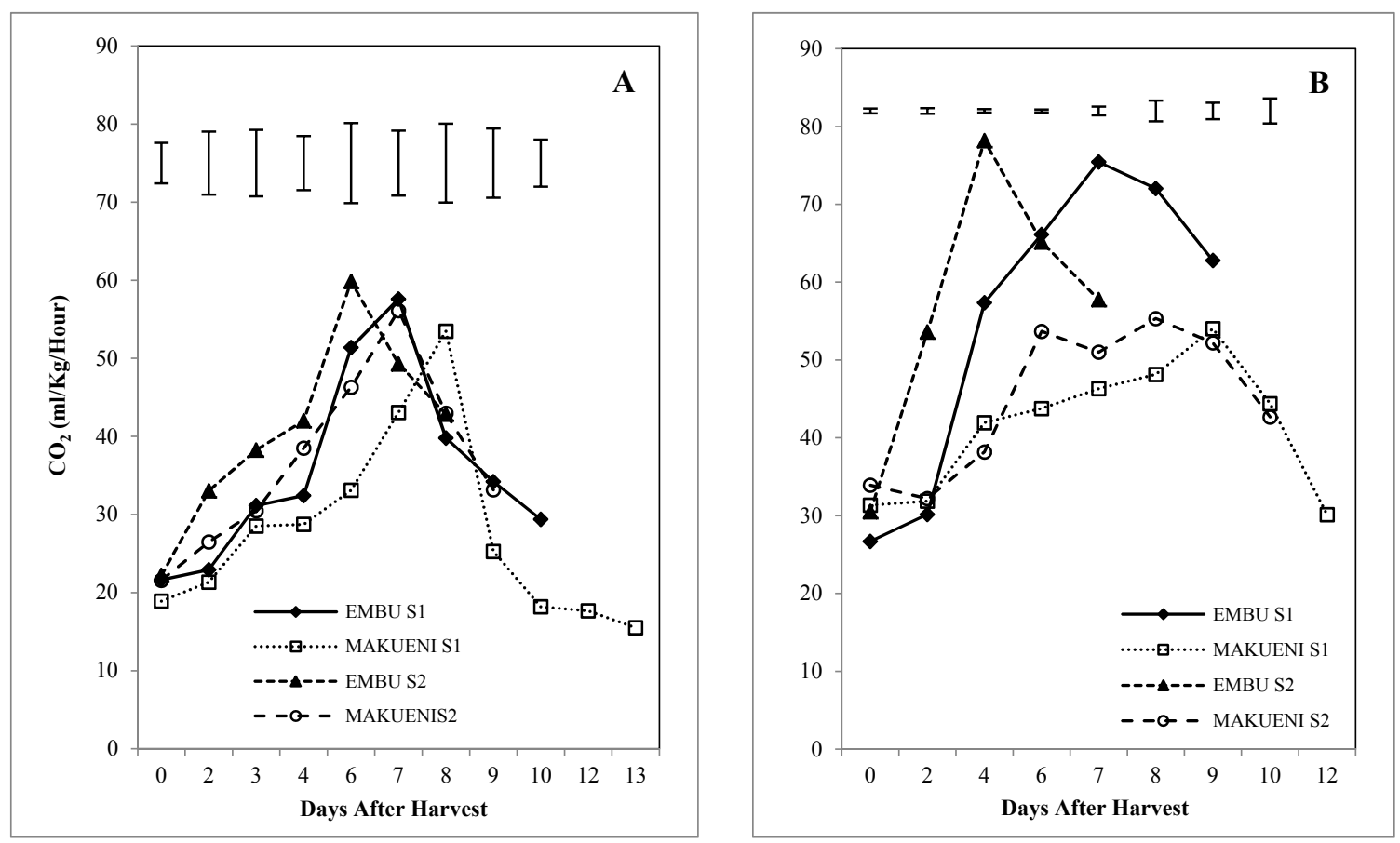

Figure 1. Changes in $\mathrm{CO}_{2}$ production of 'apple' mango harvested from Embu and Makueni at two stages of maturity; mature green (S1) and advanced in maturity (S2) in season 1A and season 2B

Note. Bars above the graph represent LSD at $\mathrm{p} \leq 0.05$ for the four means on each sampling day.

\subsection{Percent Cumulative Weight Loss}

The percent cumulative weight loss increased with fruit ripening in both season 1 and 2 (Figures 2A and 2B). Fruits harvested at S1 retained significantly $(\mathrm{p}<0.05)$ higher percentage of their initial weight than at fruits S2. Similarly, Makueni fruits retained significantly $(\mathrm{p}<0.05)$ higher percentage of their initial weight compared to fruits from Embu. In season 1, fruits harvested at S1 from Embu lost 11.5\% of their initial weight at day 10 compared to $10 \%$ at day 12 for fruits from Makueni. Fruits harvested at S2 from Embu lost $10.5 \%$ at day 8 compared to $10.3 \%$ a day later for fruits from Makueni. In season 2, fruits at S1 lost $10 \%$ at day 9 and $11.6 \%$ three days later while at S2 fruits lost $8.9 \%$ at day 7 and $8.4 \%$ of their initial weight at day 12 , respectively for Embu and Makueni. 

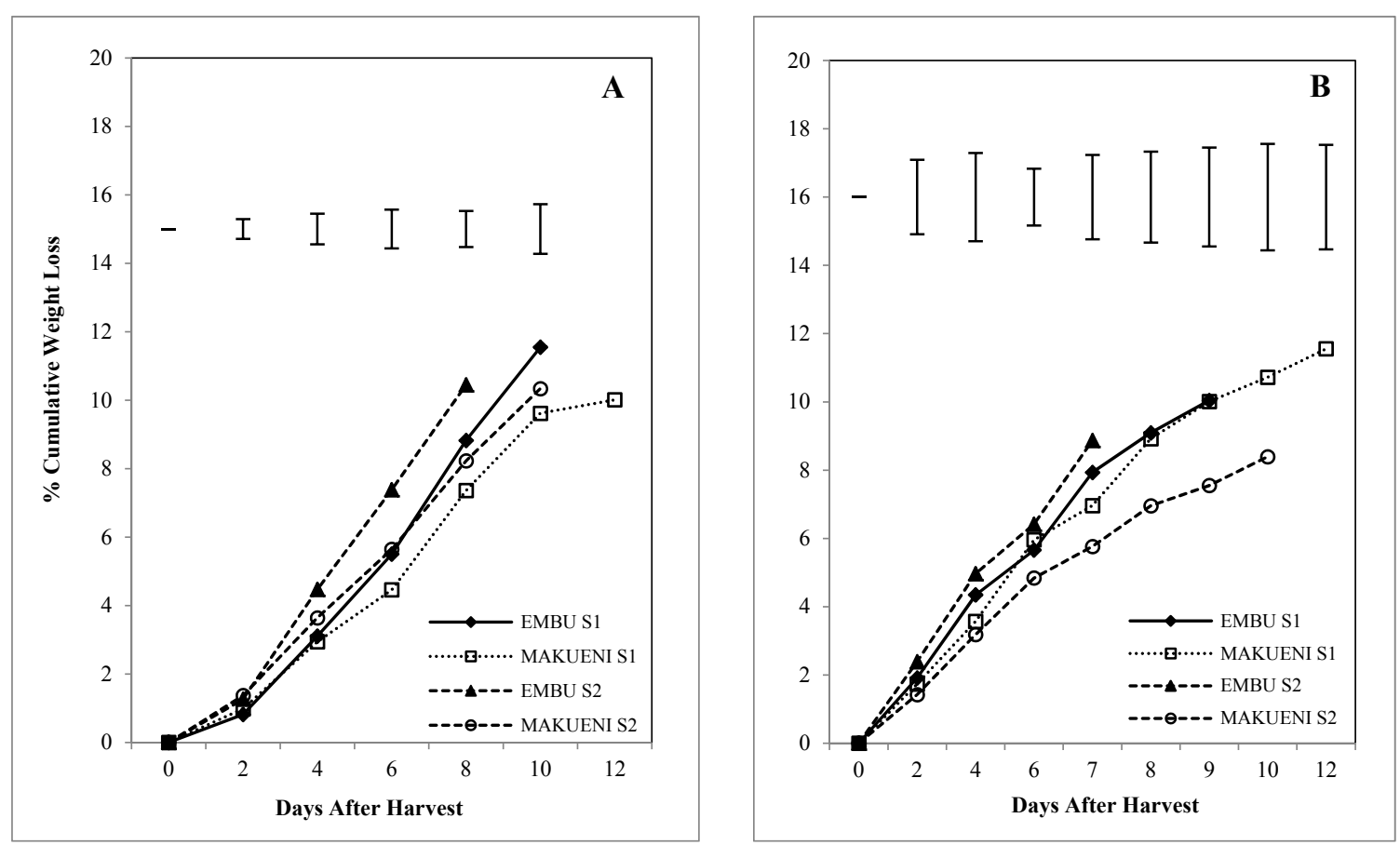

Figure 2. Changes in cumulative weight loss of 'apple' mango harvested from Embu and Makueni at two stages of maturity; (S1) and (S2) in season 1A and season 2B

Note. Bars above the graph represent LSD at $\mathrm{p} \leq 0.05$ for the four treatment means on each sampling day.

\subsection{Total Soluble Solids (TSS)}

Observations on fruit TSS showed an increase with progress in ripening (Figures 3A and 3B). In season 1, the TSS levels gradually increased from the initial values of 4.3 and $3.4^{\circ} \mathrm{Brix}$ for S1 fruits and 5.3 and $5.4^{\circ}$ Brix for S2 fruits from Makueni and Embu respectively at the end of storage period. S1 fruits harvested from Embu had the lowest TSS levels throughout the storage period. In season 2, relatively higher TSS levels were observed than in season 1 . Similar to season 1, the TSS levels gradually increased from the initial values of 5.4 and $4.7^{\circ}$ Brix to 12.6 and 9 ${ }^{\circ}$ Brix for S1 fruits and from initial values of 6.2 and 4.9 to 10.8 and $13.8^{\circ}$ Brix for S2 fruits from Makueni and Embu respectively. Fruits harvested from Makueni at S2 maintained significantly $(p<0.05)$ higher TSS levels compared to those from Makueni at S1 during their storage period. At the end of storage, fruits harvested at S2 had the highest TSS levels in both seasons. In both seasons, TSS content was significantly $(\mathrm{p}<0.001)$ affected by the interaction between location and stage of maturity. 

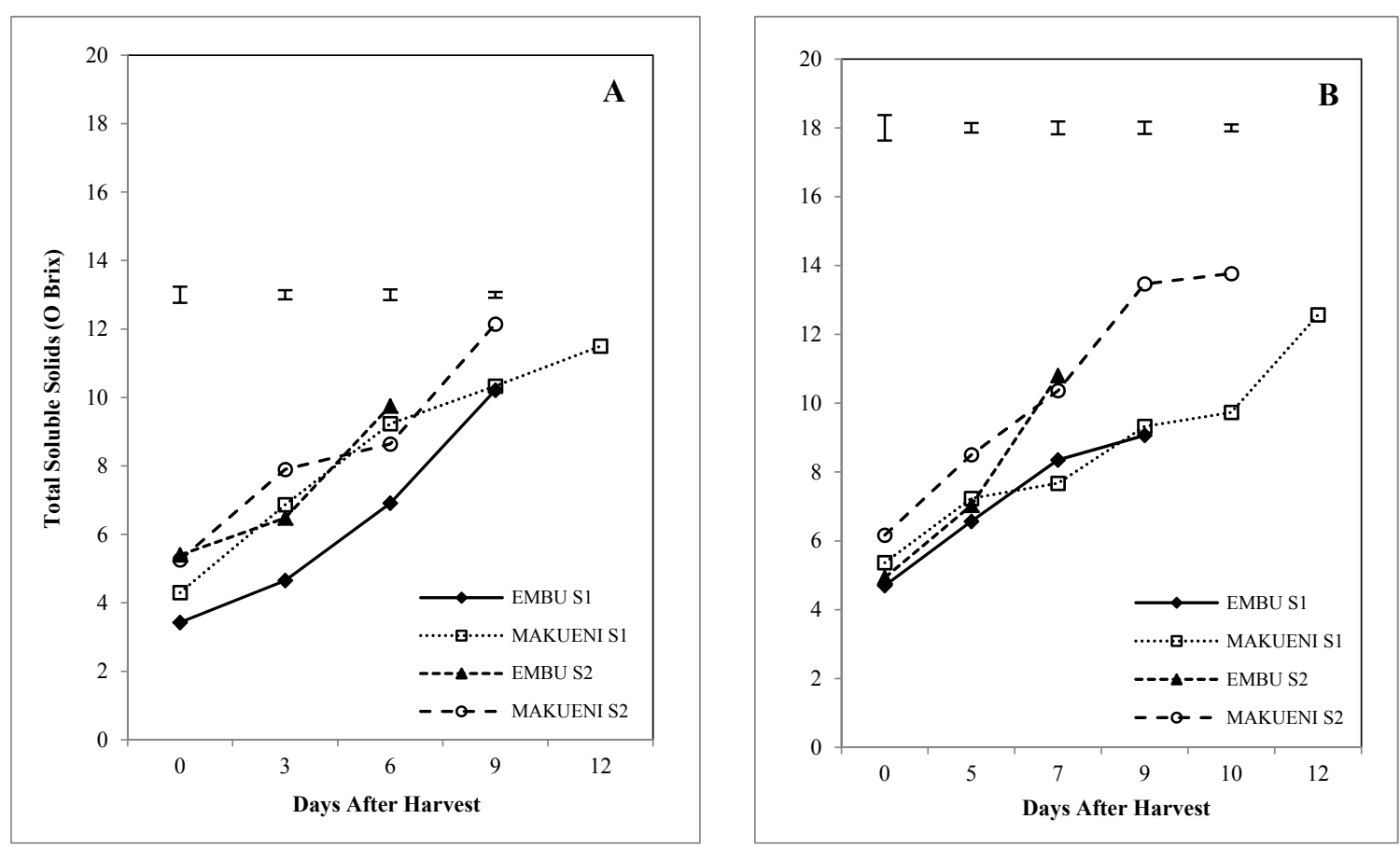

Figure 3. Changes in total soluble solids of 'apple' mango harvested from Embu and Makueni at two stages of maturity; (S1) and (S2) in season 1A and season 2B

Note. Bars above the graph represent LSD at $\mathrm{p} \leq 0.05$ for the four means on each sampling day.

\subsection{Total Titratable Acidity (TTA)}

The level of TTA reduced gradually in all the fruits as they ripened (Figures 4A and 4B). Fruits harvested at S1 had significantly $(\mathrm{p}<0.05)$ higher TTA content than those at $\mathrm{S} 2$ regardless of production location and season. In season 1, the TTA levels gradually reduced from the initial values of 0.56 and $0.65 \%$ to 0.03 and $0.1 \%$ for S1 fruits and from the initial 0.34 and $0.4 \%$ to 0.03 and $0.18 \%$ citric acid equivalent for S2 fruits from Makueni and Embu respectively, at the end of storage. Fruits harvested from Makueni at S1 retained significantly lower TTA levels during their entire storage than fruits from Embu at S1. In season 2, the TTA levels of fruits at S1 gradually reduced from the initial values of 0.6 and $0.7 \%$ to 0.07 and $0.14 \%$ and from the initial $0.55 \%$ and $0.62 \%$ to $0.11 \%$ and $0.21 \%$ citric acid equivalent for S2 fruits from Makueni and Embu respectively at the end of storage period. 

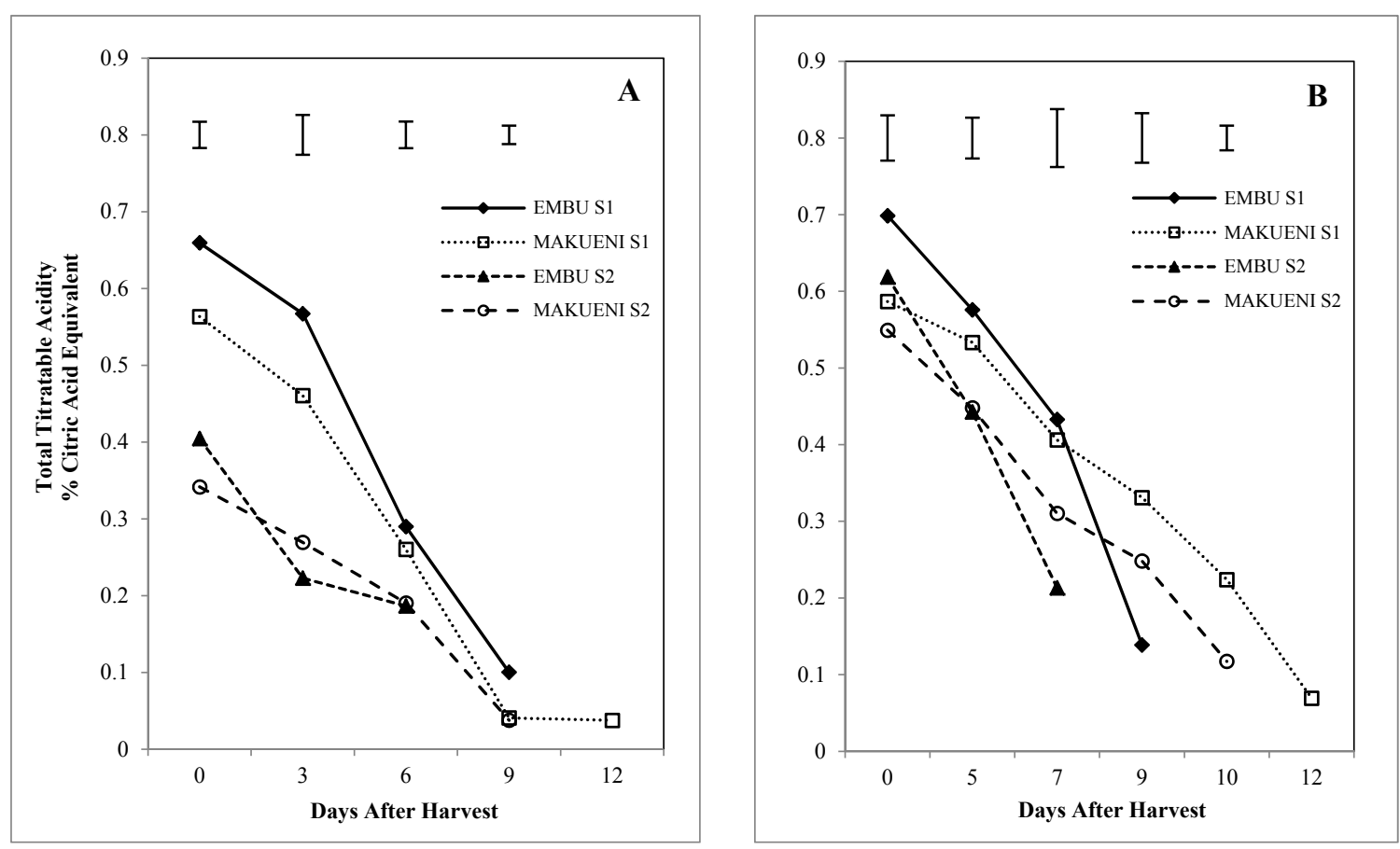

Figure 4. Changes in total titratable acidity of 'apple' mango harvested from Embu and Makueni at two stages of maturity; (S1) and (S2) in season 1A and season 2B

Note. Bars above the graph represent LSD at $\mathrm{p} \leq 0.05$ for the four means on each sampling day.

\subsection{Ascorbic Acid}

As ripening progressed, the levels of ascorbic acid reduced in all the fruits (Figures 5A and 5B). Fruits harvested at S1 had significantly $(\mathrm{p}<0.05)$ higher ascorbic acid levels compared to S2 fruits irrespective of the production location and season. Fruits from Makueni (both stages) had higher initial ascorbic acid levels in both seasons. In season 1, the initial ascorbic acid content in S1 fruits was 98.85 and $85.64 \mathrm{mg} / 100 \mathrm{ml}$ while S2 fruits had 82.78 and $77.44 \mathrm{mg} / 100 \mathrm{ml}$ respectively for Makueni and Embu. Fruit ascorbic acid content was significantly ( $<<$ $0.001)$ affected by the interaction between location and stage of maturity in season 1 . Significantly $(\mathrm{p}<0.05)$ higher initial levels of ascorbic acid were observed in season 2. In season 2, the initial ascorbic acid content in S1 fruits was 110.5 and $104.5 \mathrm{mg} / 100 \mathrm{ml}$ while S2 fruits had 106.3 and $96.3 \mathrm{mg} / 100 \mathrm{ml}$ respectively for Makueni and Embu. Fruits harvested from Makueni at both stages of maturity retained significantly $(p<0.05)$ high ascorbic content during their storage period compared to fruits from Embu. 

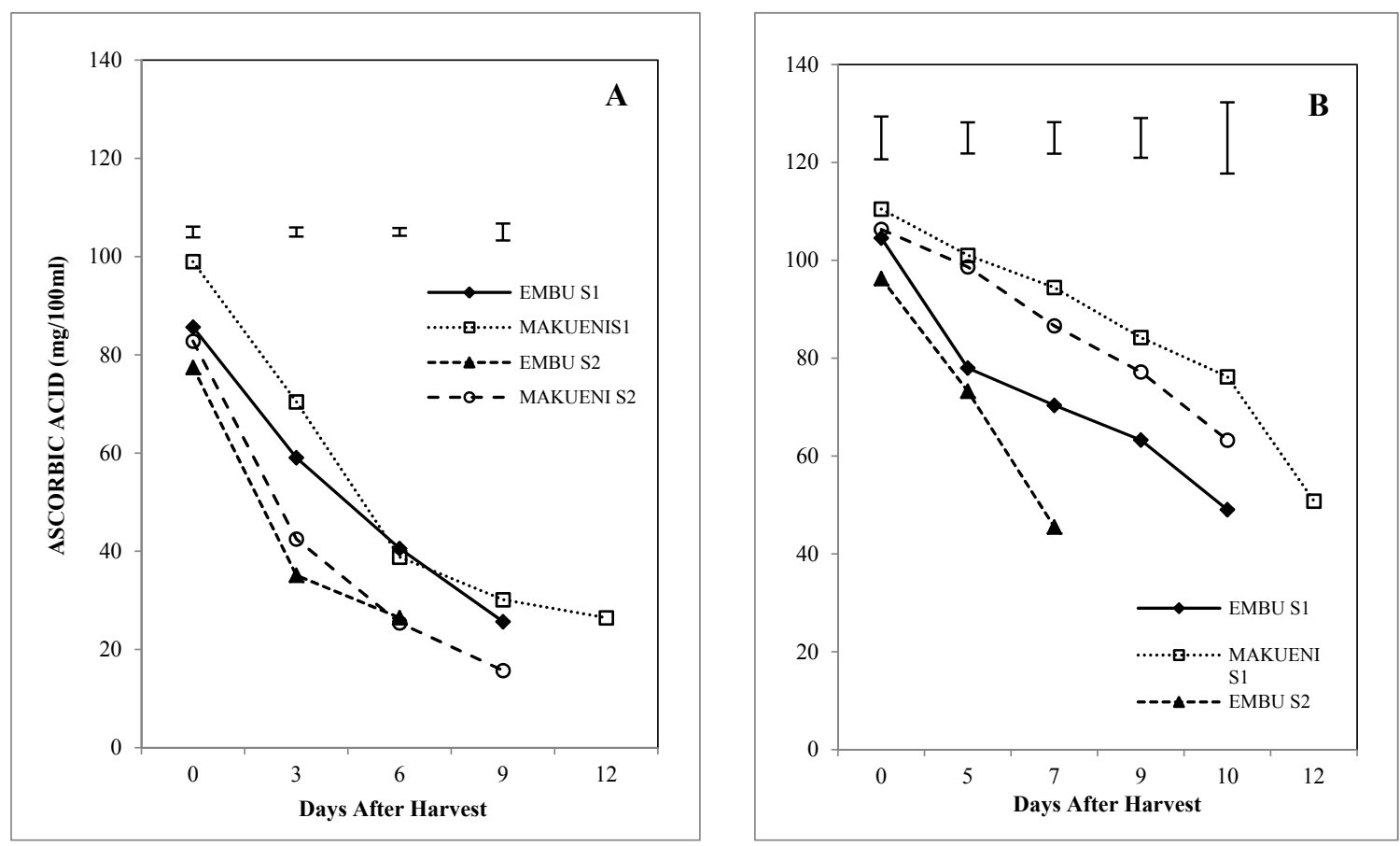

Figure 5. Changes in ascorbic acid content of 'apple' mango harvested from Embu and Makueni at two stages of maturity; (S1) and (S2) in season 1A and season 2B

Note. Bars above the graph represent LSD at $\mathrm{p} \leq 0.05$ for the four means on each sampling day.

\subsection{Changes in Magnesium Content}

A decline in $\mathrm{Mg}$ content was noted in all fruits as they ripened (Table 1). Fruits harvested at $\mathrm{S} 1$ had significantly $(p<0.05)$ higher Mg content than at S2 irrespective of location of production. Fruits from Makueni had higher initial Mg levels compared to fruits from Embu. The levels of $\mathrm{Mg}$ reduced gradually from initial values of 20.5 and $14 \mathrm{mg} / 100 \mathrm{ml}$ to 8.9 and $5.70 \mathrm{mg} / 100 \mathrm{ml}$ for $\mathrm{S} 1$ fruits and from 17.9 and $13.2 \mathrm{mg} / 100 \mathrm{ml}$ to 2.2 and 4.1 $\mathrm{mg} / 100 \mathrm{ml}$ for S2 fruits from Makueni and Embu in that order, at the end of storage. Fruits from Makueni retained significantly $(\mathrm{p}<0.05)$ higher $\mathrm{Mg}$ levels during their entire storage compared to fruits from Embu. However, fruits from Makueni at S2 retained significantly $(\mathrm{p}<0.05)$ higher Mg levels during their entire storage than fruits from Embu at S2.

Table 1. Changes in magnesium content $(\mathrm{mg} / 100 \mathrm{ml})$ of 'apple' mango harvested from Embu and Makueni at stage 1 (S1) and stage 2 (S2)

\begin{tabular}{lllllll}
\hline \multirow{2}{*}{ Location * Stage } & \multicolumn{5}{c}{ Days After Harvest } \\
\cline { 2 - 6 } & 0 & 5 & 7 & 9 & 10 & 12 \\
\hline EMBU S1 & $14.0 \mathrm{c}$ & $7.3 \mathrm{c}$ & $9.5 \mathrm{a}$ & $5.7 \mathrm{~b}$ & \\
EMBU S2 & $13.2 \mathrm{~d}$ & $6.2 \mathrm{~d}$ & $4.1 \mathrm{~b}$ & & \\
MAKUENI S1 & $20.5 \mathrm{a}$ & $15.7 \mathrm{~b}$ & $10.6 \mathrm{a}$ & $5.3 \mathrm{c}$ & $14.1 \mathrm{a}$ & 8.9 \\
MAKUENI S2 & $17.9 \mathrm{~b}$ & $16.7 \mathrm{a}$ & $10.5 \mathrm{a}$ & $12.5 \mathrm{a}$ & $2.2 \mathrm{~b}$ & \\
\hline LSD & $\mathbf{1 . 0 7}$ & $\mathbf{0 . 7 6}$ & $\mathbf{1 . 2 4}$ & $\mathbf{1 . 4 6}$ & $\mathbf{2 . 7 8}$ \\
\hline
\end{tabular}

Note. Means within column followed by a different letter differ significantly at $(\mathrm{p}<0.05)$.

\subsection{Changes in Potassium Content}

The potassium content of fruits decreased non-linearly with progress in ripening (Table 2). Significantly $(\mathrm{p}<$ 0.05 ) high $\mathrm{K}$ content was observed in fruits harvested at $\mathrm{S} 1$ than at $\mathrm{S} 2$ irrespective of the production location. Fruits from Embu had significantly $(\mathrm{p}<0.05)$ high $\mathrm{K}$ content than fruits from Makueni. The $\mathrm{K}$ levels reduced from initial values of 95.1 and $281.4 \mathrm{mg} / 100 \mathrm{ml}$ to 15.0 and $53.8 \mathrm{mg} / 100 \mathrm{ml}$ for $\mathrm{S} 1$ fruits and from initial 80.1 
and $195.1 \mathrm{mg} / 100 \mathrm{ml}$ to 72.7 and $88.8 \mathrm{mg} / 100 \mathrm{ml}$ for $\mathrm{S} 2$ fruits from Makueni and Embu respectively, at the end of storage. Potassium content was significantly $(\mathrm{p}<0.001)$ affected by the interaction between location and stage of maturity.

Table 2. Changes in potassium content (mg/100ml) of 'apple' mango harvested from Embu and Makueni at stage 1 (S1) and stage 2 (S2).

\begin{tabular}{lllllll}
\hline \multirow{2}{*}{ Location * Stage } & \multicolumn{5}{c}{ Days After Harvest } \\
\cline { 2 - 6 } & 0 & 5 & 7 & 9 & 10 & 12 \\
\hline EMBU S1 & $281.4 \mathrm{a}$ & $68.8 \mathrm{~b}$ & $86.8 \mathrm{a}$ & $53.8 \mathrm{~b}$ & \\
EMBU S2 & $195.1 \mathrm{~b}$ & $118.8 \mathrm{a}$ & $88.8 \mathrm{a}$ & & & \\
MAKUENI S1 & $95.1 \mathrm{c}$ & $76.3 \mathrm{~b}$ & $73.4 \mathrm{a}$ & $84.2 \mathrm{a}$ & $93.8 \mathrm{a}$ & 15.0 \\
MAKUENI S2 & $80.1 \mathrm{~d}$ & $66.3 \mathrm{~b}$ & $86.3 \mathrm{a}$ & $74.3 \mathrm{a}$ & $72.7 \mathrm{a}$ \\
\hline LSD & $\mathbf{1 4 . 8 5}$ & $\mathbf{1 8 . 8}$ & $\mathbf{1 3 . 3 9}$ & $\mathbf{1 9 . 7 5}$ & $\mathbf{3 4 . 0 2}$ \\
\hline
\end{tabular}

Note. Means within column followed by a different letter differ significantly at $(\mathrm{p}<0.05)$.

\section{Discussion}

Respiration is one of the major metabolic processes in harvested commodities. It is the central metabolic process in harvested produce and therefore, respiration rate sets the pace of other changes that occur after harvest (Kays, 1991). According to Day (1993), respiration rate is inversely proportional to shelf-life of the produce; the lower the respiration rates the longer the shelf-life. In the present study, ripening changes followed a similar trend to that of the fruits' respiratory activity. Maturity stage and production location all affected the respiratory activity of the fruits. Fruits produced from Makueni had relatively lower respiration rates which translated to prolonged shelf life compared to fruits from Embu that recorded significantly high respiration rate leading to a reduced postharvest shelf life. Similarly the relatively lower respiration rates in S1 fruits translated into a longer shelf life compared to S2 fruits. The effect of production location on respiratory activity and ultimately on the shelf life is attributed to the effect on fruit growth and developmental processes and hence their physiological condition at harvest. Lower respiration rates were observed in fruits from Makueni (a low potential AEZ). Previous studies have shown that production conditions or seasons with low rainfall amounts variably affect fruits postharvest behavior. In banana, fruits produced under dry conditions had relatively longer shelf life compared to those produced under relatively wet conditions (Ambuko et al., 2006, 2013). In avocado, Woolf et al. (2000) showed that fruits that ripened under sunny conditions had reduced respiration rate compared to those that ripened under less sunny conditions.

An increase in weight loss was observed in all the fruits as ripening progressed. The observed weight loss during fruit ripening is attributed to water loss due to transpiration and respiration. Previous studies reported similar findings in mango (Githiga, 2012), passion fruits (Baraza et al., 2012) and banana (Ambuko et al., 2006). The increase in weight loss was slightly lower in fruits harvested at S1 than fruits at S2. This can be explained by higher respiration rates recorded in fruits at S2 compared to relatively lower respiration rates in fruits at S1. The loss of weight from fruits from the two locations was almost comparable although fruits harvested from Makueni lost slightly lower percent of weight compared to fruits from Embu.

There was a gradual increase in the TSS levels as ripening progressed. Fruits harvested at advanced maturity (S2) had relatively higher TSS. The observed increase in TSS during ripening is associated with hydrolysis of complex carbohydrates including starch into simple soluble sugars required for cellular respiratory activity (Ninio et al., 2003). Fruits harvested from Makueni had significantly high TSS levels than fruits from Embu. The high TSS levels in fruits from Makueni may be due to the longer period of sunlight exposure during the production period leading to increased accumulation of dry matter content. Fruits trees with high dry matter content tend to accumulate more soluble solids (Hollinger, 1996). A positive relationship between light exposure period and TSS levels was previously reported in kiwi fruits (Tombesi et al., 1993) and banana (Ambuko et al., 2006).

The TTA levels reduced as the fruits ripened irrespective of maturity stage and production location. The reduction in acidity may be due to the degradation of citric acid which could be attributed to its conversion to respiratory substrates required by the cells (Abbasi et al., 2009). Fruits harvested at S1 had significantly higher TTA levels compared to those at S2 which mirrored the differences in their respiratory activity. These results 
correspond with previous findings in mango (Srinivasa et al., 2002; Githiga, 2012) where titratable acidity levels reduced with ripening. The TTA content was significantly higher in fruits harvested from Embu (a high AEZ). This could be attributed to lower accumulation of dry matter content affecting sugar content during the season of production (Hollinger, 1996). Similarly the levels of ascorbic acid reduced gradually with fruit ripening in both maturity stages and production location. Previous studies in passion fruit (Yumbya, 2012) and pepper (Howard et al., 1994) have also reported a decrease in ascorbic acid as fruits ripened. The decrease in the vitamin C levels during ripening is attributed to degradation of ascorbic acid through oxidation (Appiah et al., 2011). Contrary to the present findings ascorbic acid levels increased with ripening in apricots, papaya and peaches (Wenkam, 1979). In the present study, Makueni fruits had significantly high ascorbic acid content than Embu fruits. This is probably due to variation in production factors between the two locations with Makueni being hotter and subject to higher sunlight intensity. Previous studies show that fruits exposed to full sun accumulated high ascorbic acid due to lower respiratory activities during maturation (Weston \& Barth, 1997).

Slightly higher levels of the mineral elements were observed in fruits harvested at S1 than at S2 and the levels were affected by production location. The levels of $\mathrm{Mg}$, and $\mathrm{K}$ reduced non-linearly with advancement in fruit ripening. The reduction in $\mathrm{Mg}$ levels is attributed to the degradation of chlorophyll as ripening progressed (Medlicott et al., 1990). Fruits harvested from Makueni had significantly high Mg content at harvest. This could be attributed to higher light intensity received during growth period that may have enhanced photosynthetic activity and hence more chlorophyll accumulation (Hewett, 2006). Potassium (K) is important in metabolite transport and also plays a major role in stomata aperture size regulation hence controlling tree water loss. In the current study, $\mathrm{K}$ was the predominant element observed in the mango fruits. The significantly high $\mathrm{K}$ levels detected in fruits from Embu unlike fruits from Makueni could be attributed to variation in soil type and also increased use of $\mathrm{K}$ containing fertilizers in Embu orchard as revealed in soil analysis results.

\section{Conclusion}

The results of the present study evidently show the effect of agro-ecological zones and maturity stage at harvest on postharvest characteristics of mango fruits. Production factors especially light, temperature, water availability and the farmers' agronomic practices greatly influence fruit growth and development and consequently affect postharvest characteristics of fruits such as mangost fruit quality.

\section{Acknowledgements}

The authors wish to acknowledge the Government of Kenya for funding this research under the Kenya Agricultural Productivity and Agribusiness Project - KAPAP CGS $-2^{\text {nd }}$ CRG/FP/FRUITS/2013. Special thanks goes to the smallholder mango farmers in Makueni and Embu Counties of Kenya who gave us unlimited access to their orchards.

\section{References}

Abbasi, N. A., Zafar, I., Maqbool, M., \& Hafiz, I. A. (2009). Postharvest quality of mango (Mangifera indica L.) fruit as affected by chitosan coating. Pakistan Journal of Botany, 41(1), 343-357.

Ambuko, J. L., Sekozawa, Y., Sugaya, S., Itoh, F., Nakamura, K., \& Gemma, H. (2006). Effect of seasonal variation, cultivar and production system on some postharvest characteristics of the banana. Acta Horticulturae, 712, 505-510. https://doi.org/10.17660/ActaHortic.2006.712.61

Ambuko, J., Githiga, R. W., Hutchinson, M. J., Gemma, H., \& Owino, W. O. (2012). Effect of maturity stage and variety on the efficacy of 1-MCP treatments in mango fruits. Acta Horticulturae, 934, 719-726. https://doi.org/10.17660/ActaHortic.2012.934.94

Appiah, F., Kumah, P., \& Idun, I. (2011). Effect of ripening stage on composition, sensory qualities and acceptability of keitt mango (Mangifera indica L.) chips. African Journal of Food, Agriculture, Nutrition and Development, 11, 5-10. https://doi.org/10.4314/ajfand.v11i5.70439

Austin, P. T., Hall, A. J., Gandar, P. W., Warrington, I. J., Fulton, T. A., \& Halligan, E. A. (1999). Compartment model of the effect of early-season temperatures on potential size and growth of 'Delicious' apple fruits. Annals of Botany, 83, 129-143. https://doi.org/10.1006/anbo.1998.0804

Baraza, A., Ambuko, J., Kubo, Y., \& Owino, W. O. (2012). Effect of 1-MCP in extending postharvest life of purple passion fruit. Acta Horticulturae, 1007, 73-80.

Behboudian, M. H., \& Mills, T. M. (1997). Deficit irrigation in deciduous orchards. Horticultural Reviews, 21, 105-131. https://doi.org/10.1002/9780470650660.ch4 
Crisosto, C. H. (1994). Stone fruit maturity indices: A descriptive review. Postharvest News Information, 5(6), 65-68.

Cutting, J. M., Wolstenholme, B. N., \& Hardy, J. (1992). Increasing relative maturity alters the base mineral composition and phenolic concentration of avocado fruit. Horticultural Science, 67, 761-768. https://doi.org/10.1080/00221589.1992.11516307

Day, B. (1993). Fruits and vegetables. In R. T. Parry (Ed.), Principles and Applications of MAP of Foods. Blackie Academic and Professional, New York, USA. https://doi.org/10.1007/978-1-4615-2137-2_6

Ferguson, I. B., \& Boyd, L. M. (2002). Inorganic nutrients and fruit quality. In M. Knee (Ed.), Fruit Quality and its Biological Basis (pp. 15-45). England: Sheffield Academic Press.

Ferguson, I., Volz, R., \& Woolf, A. (1999). Preharvest factors affecting physiological disorders of fruit. Postharvest Biology and Technology, 15, 255-262. https://doi.org/10.1016/S0925-5214(98)00089-1

Githiga, R. W. (2012). Effect of 1-Methylcyclopropene and Activebag packaging on the postharvest characteristics of mango fruit (Mangifera Indica L.) cultivar Tommy Atkins (MSc. Thesis, University of Nairobi, Kenya).

Griesbach, J. (2003). Mango Growing in Kenya. International Center for Research in Agroforestry, Nairobi, Kenya.

Hewett, E. W. (1997). Fruit quality and tree nutrition. In L. D. Currie \& P. Loganathan (Eds.), Proceedings of Workshop Nutritional Requirements of Horticultural Crops. Occasional Report Number 10 (pp. 159-171). Massey University Fertilizer and Lime Research Centre.

Hofman, P. J., Smith, L. G, Holmes, R., Campbell, T., \& Meiburg, G. (1995). Mango fruit quality at harvest is affected by production conditions. Proceedings of Mango 2000 marketing seminar and production workshop (pp. 199-208). Brisbane, Australia.

Hollinger, D. Y. (1996). Optimality and nitrogen allocation in a tree canopy. Tree Physiology, 16, 627-634. https://doi.org/10.1093/treephys/16.7.627

Horticultural Crops Development Authority (HCDA). (2010). Horticultural Data 2010. Validation Report. HCDA, Nairobi, Kenya.

Horticultural Crops Development Authority (HCDA). (2011). Horticultural Data 2011. Validation Report. HCDA, Nairobi, Kenya.

Howard, L. R., Smith, R. T., Wagner, A. B., Villalon, B., \& Burns, E. E. (1994). Pro-vitamin A and ascorbic acid content of fresh pepper cultivars (Capsicum annuum) and processed jalapenos. Journal of Food Science, 59, 362-365. https://doi.org/10.1111/j.1365-2621.1994.tb06967.x

Kays, S. J. (1991). Postharvest physiology of perishable plant products (pp. 149-316). Vas Nostrand Rein Hold Book, AVI Publishing Company. https://doi.org/10.1007/978-1-4684-8255-3

Kays, S. J. (1999). Preharvest factors affecting quality. Postharvest Biology and Technology, 15, $233-247$. https://doi.org/10.1016/S0925-5214(98)00088-X

Lalel, H. J. D., Singh, Z., \& Tan, S. C. (2003a). The role of ethylene in mango fruit aroma volatile biosynthesis. Journal of Horticultural Science and Biotechnology, 78, 485-495. https://doi.org/10.1080/14620316.2003. 11511653

Medlicott, A. P. (1990). Ripening of mangoes following low temperature storage. Journal of America Society Horticulture Science, 15, 115-430.

Ninio, E., Lewinsohn, Y. M., \& Sitrit, Y. (2003). Changes in sugars, acids and volatiles during ripening of Koubo (Cereus peruvianus (L.) Miller) fruit. Journal of Agriculture and Food Chemistry, 51, 425-429. https://doi.org/10.1021/jf020840s

Silva, F. P., Silva, M. D., da Costa, A. A., \& Ramos, J. G. (2008). Productive performance of Japanese plum cultivars in Caldas, Minas Gerais State. Agronomy, 39(2), 241-249.

Simmons, S. L., Hofman, P. J., \& Hetherington, S. E. (1995). The effects of water stress on mango fruit quality. Proceedings of Mango 2000 marketing seminar and production workshop (pp. 191-197). Brisbane, Australia.

Simmons, S. L., Hofman, P. J., Whiley, A. W., \& Hetherington, S. E. (1998a). Effects of leaf: fruit ratios on fruit growth, mineral concentration and quality of mango (Mangifera indica L. cv. Kensington Pride). Journal of 
Horticulture Science and Biotechnology, 73, 367-374. https://doi.org/10.1080/14620316.1998.11510987

Srinivasa, P. C., Baskaran, R., Ramesh, M. N., Prashanth, K. V. H., \& Tharanathan, R. N. (2002). Storage studies of mango packed using biodegradable chitosan film. European Food Research Technology, 215, 504-508. https://doi.org/10.1007/s00217-002-0591-1

Thompson, A. K. (2003). Fruits and vegetables harvesting, handling and storage. Blackwell Publishers Limited.

Tombesi, A., Antognozzi, E., \& Palliotti, A. (1993). Influence of Light Exposure on Characteristics and Storage Life of Kiwifruit. New Zealand Journal of Crop Horticulture Science, 21, 87-92. https://doi.org/10.1080/ 01140671.1993.9513750

Wenkam, N. S. (1979). Nutritional aspects of some tropical plant foods. In G. E. Inglett, \& G. Charalambous (Eds.), Tropical Foods: Chemistry and Nutrition (Vol. 2, pp. 341-350). Academic Press, New York. https://doi.org/10.1016/B978-0-12-370902-8.50005-8

Weston, L. A., \& Barth, M. M., (1997). Preharvest factors affecting postharvest quality of vegetables. Horticulture Science, 32, 812-816.

Yumbya, P. M. (2012). Effect of different concentrations of 1-Methylcyclopropene and Active bag packaging on the postharvest shelf life and quality of purple passion fruits (MSc. Thesis, University of Nairobi, Kenya).

\section{Copyrights}

Copyright for this article is retained by the author(s), with first publication rights granted to the journal.

This is an open-access article distributed under the terms and conditions of the Creative Commons Attribution license (http://creativecommons.org/licenses/by/4.0/). 